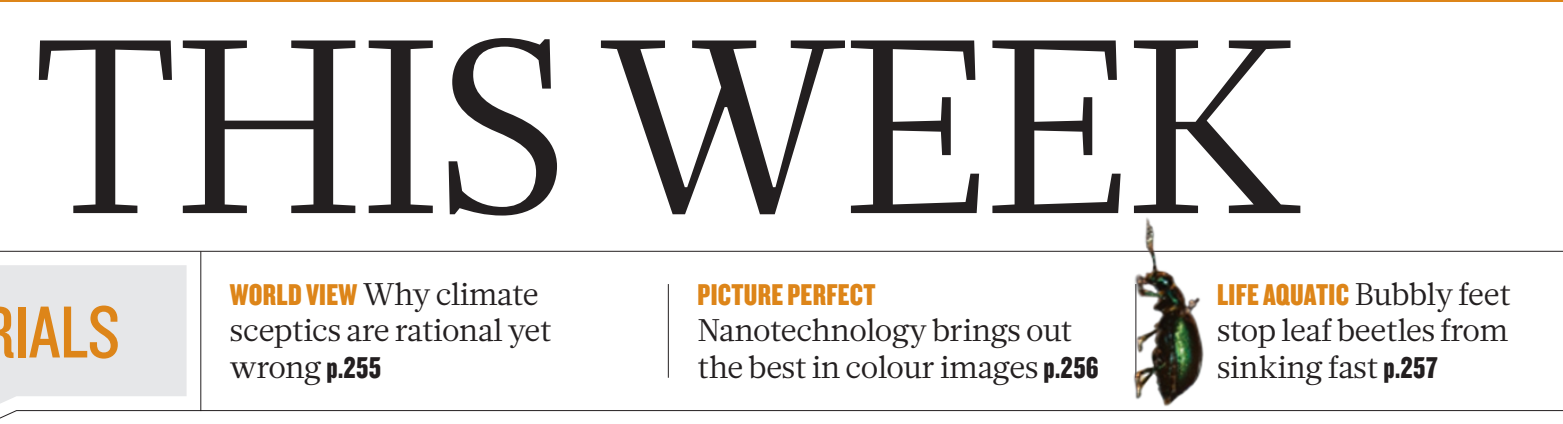

\title{
Repeat after me
}

\section{With plagiarism seemingly endemic in Romania, as well as rife among Europe's political class, a bid by academics to root out misconduct deserves widespread support.}

$\mathrm{E}$ lena Ceauşescu did not have a BSc, but the power of her husband Nicolae - Romania's dictator until communism fell - still made sure that the University of Bucharest awarded her a $\mathrm{PhD}$ in chemistry. The contents of her many scientific papers were penned by others.

The couple were executed on Christmas Day 1989 for crimes more terrible than poor publication ethics. But their practice of playing fast and loose with academic principles has flourished in notoriously corrupt post-communist Romania.

Over the past 18 months, Nature has chronicled an epidemic of plagiarism involving prominent political figures in Europe, reporting, among others, on Germany's former defence minister Karl-Theodor zu Guttenberg, who plagiarized material for his law thesis; Hungary's former president Pál Schmitt, whose thesis on physical education contained plagiarized material; as well as Romania's prime minister Victor Ponta, who continues to dismiss well-founded accusations that he plagiarized sources for his law thesis. On page 264, we highlight widespread plagiarism within Romania's universities and the worrying fact that so many academics there seem not to realize why this is a problem.

Plagiarism seems to be disturbingly prevalent among the European political class and in Romanian academia, but cases continue to pop up everywhere. The Internet makes it easier to detect, but also easier to perpetrate, because anyone can cut and paste more or less anything in a matter of seconds. Perhaps it is this easy access to the words of others that encourages some academics to think that plagiarism is not a serious issue.
They are wrong. Plagiarism is illegal (theft of intellectual property) and immoral, and anyone whose reputation and career rely on publishing their ideas and findings needs to care about it. True, it does not directly affect the scientific literature in the same way as other types of misconduct such as data fabrication. But it has an indirect impact on the academic system because it helps to promote the careers of the fraudulent and the undeserving. And those who climb the academic ladder on the back of dishonest publication records often imbue their students with the same disrespect for scientific method and academic principles.

It matters on a larger scale, too. Most countries accept that to attain economic prosperity they need a robust research base, a concept enshrined in the European Union's Treaty of Lisbon. But a research base contaminated with plagiarism can never function optimally. Romania, a signatory to the treaty, seemed to be on track to a more honest and promising future when it passed its education law, designed to inject competition into its universities and root out widespread scientific misconduct. Yet that law is now being undermined by political interference in the very ethics councils that should be helping to implement it. Against this backdrop, it is easy to see why Romania's excellent scientists - and there are many of them - choose to work mostly outside the country.

A group of researchers is now trying to change things, partly through a website to track and investigate cases of misconduct in Romania. Their stated goal is to "reform and restore confidence" in the country's academic system. Scientists everywhere should back their effort and pass on their message - with appropriate attribution, of course.

\section{Safety shambles}

\section{Lax management of Fukushima clean-up intensifies concerns over Japan's nuclear future.}

$\mathrm{E}$ arlier this summer, it emerged that five people working to clean up Japan's devastated Fukushima nuclear power plant had covered their dosimeters with lead. They blocked the radiation detectors - intended to alert them when their exposure was reaching dangerous levels - late last year to allow them to work longer hours.

An announcement made last week by the Tokyo Electric Power Company (TEPCO), which runs the plant, found that the five workers were contracted by a subcontractor of a subcontractor, and had not even been authorized to work at the plant. Other workers were found who were not using the devices at all. In response, TEPCO has barred its direct subcontractor, Tokyo Energy and Systems, from bidding for contracts for three months. The ministry of health and labour is still investigating.

That such egregious flouting of safety protocols would occur despite the media attention on the clean-up efforts is astonishing. And it seems all the more so given the ongoing concern about the health risks of radiation in Japan, and that the nuclear industry's lack of transparency and cavalier attitude towards safety are fuelling a debate over atomic power that is becoming the most politically divisive in the country for decades.

That's on the ground. Decision-making looks no prettier at TEPCO headquarters. Last week, the company made available some 150 hours of video recordings of exchanges between the company and staff at its nuclear plants in the first days of the disaster. The videos highlight some uncomfortable facts that the company had previously denied - that senior officials hesitated to use sea water to cool overheating reactors for fear of damaging them, for example, despite recommendations from a local plant manager to do so.

In the days after 11 March 2011, the world saw that TEPCO's reactors were not designed to withstand disaster. Now it is becoming clear how poorly the company has dealt with the aftermath. 